\title{
RÉKA VÉGVÁRI*
}

\section{Shifts in Thinking Concerning Law of Criminal Procedure in Witness Protection}

\begin{abstract}
The essay deals with the new approach of criminal procedural law concerning witnesses. The witness protection problem has been in the center of academic discussion for the last two decades. The question has crucial importance within the European Union in light of the principle of mutual recognition. Acceptance of minimum standards in this field could facilitate the emergence of this corner stone of the judicial co-operation. The article provides an oveview on the efforts made in international and european level. Analyses the notion of witness and some principles of criminal procedure in connection with the witness protection. Finally it gives an insight into the hungarian regulation.
\end{abstract}

Keywords: Criminal procedure, procedural principles, witnesses, witness protection

\section{Introduction}

Although during the last thirty years a wider range of evidential tools have become available, witnesses have invariably had a key role in criminal proceedings. Witness statements are indispensable to the success of the investigation and the trial. The appearance as a witness on subpoena in front of the judicial authorities is generally an obligation of a person. Moreover, save in some circumstances listed in criminal procedural norms, making a statement is also mandatory, and in addition the witness is burdened by the obligation of giving a truthful testimony. Otherwise the witness has to face the consequences of a breach of this duty (perjury). Being a witness in a criminal case is not at all a comfortable position, not only for the above mentioned reasons.

Many factors have led to increased public attention on the role of witnesses in criminal proceedings. Perhaps the two most important issues have been the increased interest in the status of victims in criminal procedure and the signi-

* Research Fellow, Institute for Legal Studies of the Hungarian Academy of Sciences, H-1250, Budapest POB 25.

E-mail: rvegvari@yahoo.com OTKA T 046973. 
ficant rise in terrorism and organised crime. ${ }^{1}$ Over the last decade, intimidation by the parties to the case, and particularly of witnesses in the criminal process has become more and more frequent, and this has led to an increasing amount of allowing exceptions under legal norms for taking witness statements, for example, without the presence of the accused; or refusals in rendering incriminating testimonies. It is clear and recognised in the public debate that witnesses need protection. The main question relates to the "know-how" of this protection, i.e. to questions such as what are the possible and most effective forms of protection.

\section{Efforts in the Field of Witness Protection}

States have recently given importance to the problem of witness protection at national, European and international levels. In the context of this paper "European level" includes the endeavours within the Council of Europe (hereinafter $\mathrm{CoE}$ ) and within the European Union (hereinafter EU); the international level covers the work of United Nations (hereinafter UN).

\section{European level}

The first step was taken within the European Union by the adoption of the Resolution on the protection of witnesses in the fight against international organised crime of 23 November $1995^{2}$ (hereinafter Resolution 1995). The Resolution on individuals who co-operate with the judicial process in the fight against international organised crime of 20 December $1996^{3}$ calls on Member States to adopt appropriate measures to encourage individuals who participate or have participated in an association of criminals or other criminal organization of any kind, or in organized crime offences, to co-operate with the judicial process and to provide appropriate protection measures for any individual and, where necessary, for his parents, children and other persons close to him, who, by virtue of the individualá's willingness to cooperate with the judicial process, is or are likely to be exposed to serious and immediate danger; in considering such measures, Member States should have regard to the Resolution 1995.

${ }^{1}$ Mackarel, M.-Raitt, F.-Moody, S.: Briefing paper on legal issues and witness protection in criminal cases. Edinburg, 2001.

${ }^{2}$ OJ 1995 C327. 5.

3 OJ 1997 C10. 1. 
The Millennium Strategy ${ }^{4}$ states that a proposal shall be prepared for an instrument on the position and protection of witnesses and of persons who participate or who have participated in criminal organisations, and who are prepared to co-operate with the judicial process by supplying information useful for investigative and evidentiary purposes or by providing information that may contribute to depriving criminal organisations of their resources or of the proceeds of crime. According to Council Framework Decision of 15 March 2001 on the standing of victims in criminal proceedings, ${ }^{5}$ each Member State shall ensure that victims have a real and appropriate role in its criminal legal system, and shall recognise the rights and legitimate interests of victims with particular reference to criminal proceedings. It is necessary to ensure that victims who are particularly vulnerable can benefit from specific treatment best suited to their circumstances. Article 8. refers the victims rights to protection. ${ }^{6}$

The European Court of Justice adjudged in the Pupino case, ${ }^{7}$ that "The national court is required to take into consideration all the rules of national law and to interpret them, so far as possible, in the light of the wording and purpose of the Framework Decision".

4 The prevention and control of organized crime: a European Union strategy for the beginning of the new millennium OJ $2000 \mathrm{C} 124.1-33$.

5 2001/220/JHA, OJ L 82, 22. 3. 2001. 1-4.

6 1. Each Member State shall ensure a suitable level of protection for victims and, where appropriate, their families or persons in a similar position, particularly as regards their safety and protection of their privacy, where the competent authorities consider that there is a serious risk of reprisals or firm evidence of serious intent to intrude upon their privacy.

2. To that end, and without prejudice to paragraph 4, each Member State shall guarantee that it is possible to adopt, if necessary, as part of the court proceedings, appropriate measures to protect the privacy and photographic image of victims and their families or persons in a similar position.

3. Each Member State shall further ensure that contact between victims and offenders within court premises may be avoided, unless criminal proceedings require such contact. Where appropriate for that purpose, each Member State shall progressively provide that court premises have special waiting areas for victims.

4. Each Member State shall ensure that, where there is a need to protect victimsparticularly those most vulnerable-from the effects of giving evidence in open court, victims may, by decision taken by the court, be entitled to testify in a manner which will enable this objective to be achieved, by any appropriate means compatible with its basic legal principles.

7 http://curia.europa.eu/jurisp/cgi-bin; Judgment OJ C 193, 06. 08. 2005. 3. 
The Institute for International Research of Criminal Policy, which is integrated into the University of Ghent, conducted a research on witness protection. As a result of the work three proposals for EU framework decisions were drafted: a proposal concerning anonymous witnesses, ${ }^{8}$ a proposal concerning protected witnesses,${ }^{9}$ and a proposal concerning collaborators with justice. ${ }^{10}$

The Committee of Ministers of the CoE has adopted relevant recommendations in connection with the issue. Recommendation on the position of the victim in the framework of criminal law and procedure ${ }^{11}$ proposes that whenever this appears necessary, and especially when organised crime is involved, the victim and his family should be given effective protection against intimidation and the risk of retaliation by the offender.

Recommendation on intimidation of witnesses and the rights of the defence [R (97) 13$]^{12}$ is based on the awareness of the need for Member States to develop a common crime policy in relation to witness protection.

Recommendation on the protection of witnesses and collaborators of justice [R (2005) 9$]^{13}$ declares inter alia as a general principle that appropriate legislative and practical measures should be taken to ensure that witnesses and collaborators of justice may testify freely and without being subjected to any act of intimidation.

\section{International level}

Measures for witness protection are provided for within the Statutes of the International Criminal Tribunal for the Former Yugoslavia (1993) and for Rwanda (1994) and also in the Rome Statute. It is the duty of these institutions to provide for appropriate protective measures. Rules of Procedure and Evidence both of ICTY and ICTR contain provisions on witness protection.

\footnotetext{
${ }^{8}$ Vermeulen, G. (ed.): EU standards in witness protection and collaboration with justice. 244-250. http://www.mruni.lt/

9 Ibid. 258-268.

${ }^{10}$ Ibid. 251-257.

${ }^{11} \operatorname{Rec}(85) 11$ of the Committee of Ministers to Member States on the Position of the victim in the framework of criminal law and procedure, https://wcd.coe.int/

${ }^{12} \operatorname{Rec}(97) 13 \mathrm{E} 10$ concerning intimidation of witnesses and the rights of the defense, https://wcd.coe.int/

${ }^{13} \operatorname{Rec}(2005) 9$ of the Committee of Ministers to member states on the protection of witnesses and collaborators of justice, https://wcd.coe.int/
} 


\section{The Notion of Witness}

\section{European level}

The European Convention on Human Rights (ECHR) does not contain a definition of witness; however, from the case law of the European Court a wide notion stands out. The Court has not given any specific wording but has defined the concept in an autonomous manner with a broad scope allowed for its application. The autonomous concept is mentioned in Kostovsky, and in Isgro judgements. ${ }^{14}$ The R (97) 13 also uses a broad definition, namely, "witness" means any person, irrespective of his/her status under national criminal procedural law, who possesses information relevant to criminal proceedings. This definition also includes expert witnesses as well as interpreters. It covers those persons who have disappeared after making an initial statement, or who make statement only to the police.

The R (2005) 9 stipulates that "witness" means any person who possesses information relevant to criminal proceedings about which he/she has given and/or is able to give testimony (irrespective of his/her status and of the direct or indirect, oral or written form of the testimony, in accordance with national law), who is not included in the definition of "collaborator of justice". The definition as formulated by the Recommendation is based on the autonomous concept of witness under Article 6 of the European Convention on Human Rights. This definition includes any person who possesses relevant information to criminal proceedings about which he/she has given and/or is able to give testimony. ${ }^{15}$ Here the function of the witness has main importance rather than the status of the person concerned or the form of the testimony. These factors could differ according to the national system. The expression 'relevant' covers all the information which is pertinent for the procedure, irrespective of the importance of the information. The element of importance should be connected to the evaluation of the protection needs, but not to the qualification of witness.

\section{European Union}

In accordance with the Resolution of the Council (1995) "witness" means "any person, whatever his legal status, who possesses intelligence or information

${ }^{14}$ Kostovski v. Netherlands Judgment of 20 Nov. 1989, Series A, No. 166, Applic. No. 11454/85, (1990) 12 EHRR 434; Isgro v. Italy Judgment of 19 Feb. 1991, Series A, No. 194-A, Applic. No. 11339/8.

${ }^{15}$ Explanatory Memorandum. 
regarded by the competent authority as being material to criminal proceedings and liable to endanger that person if divulged". The resolution is connected to organised crime, and therefore it is understandable that the definition contains an element of threat.

The proposed framework decision on protected witnesses does not contain any general definition of witness. The proposal concerning anonymous witnesses presents a definition under which anonymous witness means "any person, irrespective of his status under national criminal procedural law, who provides or is willing to provide information relevant to criminal proceedings and whose identity is concealed from the parties during the pre-trial investigation or the trial proceedings though the use of procedural protective measures as specified in $(\ldots)$ ".

\section{International level}

No definition of the witness can be found in international law. According to treaties, the case law and guidelines, parties giving testimony during the criminal procedure are included. Parties include witnesses in its classical meaning in most national laws, mainly victims and other vulnerable categories. Rules of Procedure and Evidence both of the ICTY and of the ICTR contain the definition of a victim, who is a person against whom a crime over which the Tribunal has jurisdiction has allegedly been committed. ${ }^{16}$ Rules of Procedure and Evidence of the ICC also defines the notion of victim. ${ }^{17}$

\section{Hungarian law}

In domestic law the Code of Criminal Procedure provides for a definition of witness. In accordance with section 79 subsection 1 , any person can be questioned as witness, who may have information of the fact that must be proved. This is quite a broad definition of a witness to the crime; the members of the authorities giving testimony, the collaborators of justice, the eyewitnesses etc. are covered by it. According to Hungarian law and an accused and a co-accused give evidence still only in a position of an accused, not as a witness.

\footnotetext{
${ }^{16}$ Rules of Procedure and Evidence ICTY IT/32/Rev.39, Rule 2; ICTR ITR/3/Rev.1, Rule 2.

${ }^{17}$ Rules of Procedure and Evidence ICC Official Recordc ICC-ASP/1/3, Rule 85.
} 


\section{Procedural Principles and the Witness Protection Problem}

Public hearing means that criminal cases are tried in an open court. There are two meanings contained in the concept of open trial. First, a trial is open when the public can attend the trial, and second, it can be regarded as open when the hearing is not open to public as such, but it is open to all of parties of the procedure. When a trial is conducted without public access, the principle of open court is infringed. However, it is important also to take into account the interests of the parties, and balance those interests against the public interest. In some cases the restrictions are necessary and fulfil the proportionality requirements, if the parties' interest and procedural rights are taken into consideration. The balance between the parties' rights and the interest of the public is secured by making the final court decision public.

When a trial is open for the public, serious problems may emerge, if the court orders the accused to leave the court room while the witness gives evidence, where there is a danger that his or her presence may influence the witness. Not only the principle of public hearing, but also the right to fair trial can be jeopardised. This limitation of the presence of defendant is justified, when it is necessary for protection of witness, but only when other guarantees counterbalance the absence of the accused.

The principle of oral hearing means that the trial itself is conducted orally. The possibility to provide for written witness statements has an impact of this principle. The accused's right to a fair trial corresponds to the right of an oral hearing where the court is faced with an obligation to search for the material truth.

Immediacy in the court trial is the leading principle of many systems of criminal procedure. At the court trial as a rule evidence must be produced on the basis of this principle. Using a statement of an anonymous witness as means of evidence is an important exception to the immediacy principle. In addition problems arise in connection with the principle of fair trial ( $R$ (97) 13). Furthermore, the case law of the European Court has given guidelines on how to deal with the problem. Using anonymous witnesses is not against the ECHR if proper guarantees are observed. These are:

- no convictions must be based solely or to a decisive extent on the anonymous statement,

- using anonymous witnesses must be exceptional,

- proper verification procedure is needed, where the credibility and reliability of the witness is examined and the examining authority shall have full knowledge of the witnesses" identity, 
- the defence must have the right to challenge the alleged need for anonymity, of the witness, his/her credibility and the origin of his/her knowledge.

Until the last two decades the fair trial focussed almost only on the rights of the defence. The witnesses" rights were less discussed. Nowadays the importance of defence is recognised, and the procedural rights of witnesses are also accepted.

\section{Witness Protection Measures in Hungary}

Following the political transformation, an obvious change has ensued in the area of the protection of the witness. According to procedural law, a witness is under an obligation to appear and testify before the authorities upon summons. Apart from the prescription of obligations and their consequences, the state did not give attention for the proper protection of witnesses at all for a long time. It was at the discretion of authorities,-in the interest of spareing the witness the awkwardness of the situation-to make use of the modest opportunities guaranteed by law, such as the temporary removal of the accused from the courtroom or avoiding the confrontation by the parties. It is evident that the involvement of witnesses in criminal process cannot be omitted altogether; however, the risk entailed by giving evidence must also be minimized for witnesses. Appearance before the authorities and making a statement implies a stress situation in itself for the majority of witnesses. It is the duty of the state to protect those involved in the situation as much as possible from detrimental consequences or stress deriving from the situation, even if actual threat or undue influence does not exist.

So, as to accomplish the objectives above, the instruments of the protection of witnesses were gradually introduced. The protective measures that are available according to the Code of Criminal Procedure are as follows:

- non-disclosure of personal data,

- statement in a written form,

- legal counsel on the witnesses' side,

- exclusion of public during trial,

- temporary exclusion of defendant during trial,

- elimination of confrontation,

- witnesses under special protection (anonymous witness),

- direct personal protection,

- provisions on witnesses to be involved in a protection programme,

- pre-trial hearing in front of an investigating judge,

- giving evidence by means of live television link,

- restraining orders. 
It was pursuant to Act 92 of 1994 that the management of the particulars of witnesses (with the exception of their names) was facilitated for courts acting ex officio or at the request on basis of classified materials. ${ }^{18}$

Within the purview of the new ACP, the rules of the protection of witnesses are specified under a separate title, which originally contained rules on the management of personal data as classified material, on the protection of special classes of witnesses, and on the protection of the person of the witness. It is prescribed that only in exceptionally moderate cases the name of the witness, which usually is classified information, is also admissible, confrontation between the accused and the witness can be disregarde, and the introduction for recognition shall be accomplished so that the person introduced for recognition cannot recognise or see the witness, if that is necessary in re the protection of the witness.

The introduction of the rules for the specially protected or anonymous witnesses was partly justified by the requirement for increasing the efficiency of intervention against organised crime. Thereby, a person exposed to danger will not have to appear at trial, since hearing shall take place during the investigation and it is conducted by the investigative judge in the absence of the accused and the defence counsel. The declaration of a specially protected witness shall be granted on the basis that the testimony concerns an essential circumstance of a significant case and the evidence provided by the witness cannot be obtained from another source. Measures taken to protect the witness are effective, since his identity shall not be known either by the accused or the defence counsel, and without such protection the witness, his relative or property would be exposed to a serious threat.

The procedure of the declaration on a specially protected witness shall be conducted by an investigative judge. Originally the ACP did not specify the so-called verification phase as part of the procedure, in the course of which the judge is able to verify the credibility of the witness and the circumstances relating to the credibility of his testimony. The elimination of this default was particularly essential, since according to Recommendation no. R (97) 13 a verification procedure involving an anonymous witness should be integrated into the criminal procedure to properly balance the objectives of judicature and the rights of defence. This would facilitate the defence's ability to challenge the necessity for anonymity, the credibility of the witness and the source of his information. A state that has not instituted the above-mentioned procedure will likely be regarded to infringe the rules of fair trail. In Hungary the problem was solved by enacting the Supplementary Law of 2002, which prescribed for

${ }^{18}$ It entered into force on 15th February, 1995. 
the examination of the credibility of the witness and of his testimony as an obligation of the investigative judge.

The third form of protection is the protection of the person. Pursuant to amendments made in relation to the position of the accused, the defence counsel, the aggrieved or other party concerned, the representative of the aggrieved or other party concerned, or, the expert, the consultant, the interpreter, the official witness or any other person related to the afore-mentioned ones, are allowed for protection of the person. For its implementation, Government Decree no. 34 /1999 (II. 26.) formulated the conditions and rules for an order of protection of the personae involved in the criminal procedure and for officials participating in the process. The sphere of the statute encompasses also the personae of officials, prosecutors and judges. Furthermore, on the 1st of April 2002, Act 85 of 2001 on the Program of Protection of Parties (hereinafter APP) entered into force which included in the criminal procedure protection the supporters of the administration of justice, the objective of which is to guarantee protection for parties who are participating in the criminal procedure or actively support the administration of justice or are closely related to these persons, and, are threatened, and their personal security requires increased protection by the state. Its further objective is to promote the fight against crime, especially against infamous, primarily organised crime, and the effective enforcement of the interests of criminal prosecution and the administration of justice by the application of special measures adjusted to the extent of danger threatening the concerned party. ${ }^{19}$

Within the purview of APP, protection shall be guaranteed for those witnesses, aggrieved parties and offenders who are involved in criminal procedure and exposed to serious danger and who co-operate with judicature and repent.

${ }^{19}$ Framing the Act was motivated partly by the obligation of legal harmonisation entailed by accession to the EU and by the practice related to organised crime in the Member States. The statement of the Council of Europe of 1995 requires that Member States provide efficient and appropriate protection for witnesses preceding, during and following the criminal procedure. The majority of Member States provide protection for those in need in the scope of the program. This is also a solution adopted by Hungarian law. In the EU, this has become an indispensable prerequisite of co-operation against criminality, whence co-operation among Member States is accomplished by national departments implementing the program.

In December, 2000, Hungary signed the UN Convention against transnational organised crime. Its provisions concerning the protection of the witness promote the physical protection of witnesses, the removal of witnesses in danger, confidentiality of the particulars of witnesses, recourse to legislative and other measures that facilitate the arranging of videoconferences. 
Under the new ACP, separate rules are stipulated in re witnesses and the accused whose identity has been changed as a consequence of their involvement in the Protection Program. These persons participate in the procedure with their original particulars; however, the headquarters of the Witness Protection Service shall be indicated as their place of residence.

Provisions promoting the witness protection are specified not only under the new ACP. The rules of hearing witnesses stipulate hearing children in exceptional circumstances; and they allow for the possibility of the provision of written testimony, the latter of which is subsequent to and following a verbal hearing. However, if necessary, the witness may be heard also subsequently to the provision of written testimony. These rules are strengthened by provision of a restraining order and the possibility for the application of closed-circuit broadcast at the session of the investigative judge or at the trial.

Although the rules on restraining orders are placed in sections concerning coercive measures, they also partly fall within the means of witness protection.

The increase in the effectiveness of intervention against violent crime committed within families has in recent years become a fundamentally important issue of criminal policy in Hungary, and this can be partly attributed to the impact of international trends.

A restraining order may be instrumental as to the impediment and evidence of the infringement of the law within families. Several international legal documents motivate states to institute rules on limiting, restraining and safeguarding family members, designed to assure both that the accused abandons the lieu of crime and the composure of the aggrieved party at least for a transitional period. The motioned provisions may be incorporated under administrative or penal rules.

Law-makers in Hungary have opted for the latter alternative by defining the restraining order as a coercive measure with regard to the rules of the prohibition of the abandonment of residence. This, as a solution, is still disputed in criminologist circles. The accused is forced to abandon the residence and area specified by court and to avoid both returning there for a specific period and making any contact with the person specified by court.

The shortest period for a restraining order is 10 days, and the longest period is 30 days; it is not possible to request for an extension. Nonetheless, the possibility of a repeated order is not precluded by law.

The rules are applicable on condition that there is a danger that the offender impedes, encumbers or jeopardises testimony via influencing or intimidating the aggrieved party. Therefore, a restraining order indirectly also promotes the objective of the protection of the witness. A deficiency in the new regulation is that it does not admit the application of a restraining order in re other 
witnesses apart from the aggrieved party, whereas, in the testimony relating to a crime committed within a family, a crucial role is assigned to parties living in the specific neighbourhood and exposed to harassment by the offender outside their homes.

\section{Summary}

Expanding and developing the measures on witness protection are the pledge of effective international co-operation in criminal matters. The question of witness protection has extreme importance within the European Union in light of the principle of mutual recognition. Acceptance of minimum standards in this field could facilitate the emergence of this corner stone of the judicial cooperation. The concept of the witness protection should be interpreted broadly. It ought to cover not only the procedural and non-procedural means, ${ }^{20}$ but also the treatment of witnesses from the side of judicial authorities. The first stage of the witness protection is the improvement of the treatment of persons giving evidence. Similarly to the proposal for a framework decision on certain procedural rights applying in proceedings in criminal matters throughout the European Union, ${ }^{21}$ a letter of rights should be given for all witnesses or open it up for them. The trust towards the judicial authorities should be strengthened.

The definition of witness should be clarified on EU level. Witnesses' right to give evidence without intimidation and threat should be declared. Proportionality between the nature of the protection measure and the seriousness of the intimidation of the witness should be ensured. Certain minimum procedural protection should be given to every witness. In case of serious criminal offences the right of appointed legal representation should be ensured for the witness. With regard to witnesses in weaker position, e.g. children, special protective measures should apply.

The problem of anonymous witnesses should be reconsidered in connection with the principle of fair trial. Legal representation of the defendant during the verification procedure should be ensured.

\footnotetext{
${ }^{20}$ Non-procedural protection means the safeguarding of witnesses who are in danger or directly threatened, and where the application of the procedural tools are not effective per se.

${ }^{21} \mathrm{COM} / 2004 / 0328$.
} 